\title{
World Cup television
}

\author{
Felisbela Lopes, Luís Miguel Loureiro, Phillipe Vieira ${ }^{1}$
}

\begin{abstract}
In the last year of the first decade of the $21^{\text {st }}$ century, in the verge of breaking into the era of digital television, it is important to know what kind of television model is available in Portugal. The analysis of the news coverage of the FIFA 2010 World Cup will certainly help in finding the answers. In this article, we present a study that centers its focus on news formats related to this great media event, broadcasted in both generalist as well as cable news networks between the $11^{\text {th }}$ of June and the $11^{\text {th }}$ of July 2010 (the opening and closing dates of the competition). That analysis, based upon 604 broadcasts, sought to discover the means for viewer integration in television broadcasts and who was summoned by the television studios to participate in the discussions that they promoted. The data collected clearly shows that this World Cup TV is still very much closed to public participation and circumscribed to a small group of guests, most of who come from the journalistic field. It seems impossible to mention a third stage in the audiovisual world in the face of this reality. Post-television can wait.
\end{abstract}

Keywords: television, post-television, broadcasting, interactivity, participation, sport, World Cup, television news

\section{Introduction}

Television is in constant evolution. Technological innovation that allows the existence of dialogues between the production and reception instances surely widens the odds for a third stage of television. Left behind are the models of a paleo-TV, the window television that was law during the times of state-owned television monopoly; and of a neo-TV, a mirror television that appeared during the era of deregulation. To the TV that emerges with the promises of the digital world, we take into account the potential for transforming audiences/public in producers or, at least, in active partners in the process of television programming given the potential of the new technologies made available in this sector. But does the current television programming allow us to talk about a third stage in the audiovisual market? This is what we discuss in this paper in the course of the analysis of the Portuguese television news coverage of the 2010 FIFA World Cup ${ }^{2}$.

\footnotetext{
${ }^{1}$ Researchers of the Center for Communication and Society Studies (CECS), Universidade do Minho, Portugal (felisbela@ics.uminho.pt; luis.m.loureiro@gmail.com; phillipevieira@gmail.com).

2 This work is part of a research project funded by the Foundation for Science and Technology, entitled "TV journalism and citizenship: the struggle for a new digital public sphere" (FCT PTDC/CCI-JOR/099994/2008). The aim of the project is to map information programming of terrestrial channels as well as cable news channels, and to
} 
Throughout this just over half a century of television in Portugal ${ }^{3}$, it was mainly the grand media events that were responsible for evolutionary leaps in the audiovisual panorama. This was true in 1957 when Queen Elizabeth II of England visited Portugal; it was also true during the 1966 football World Cup in England, where the Portuguese team, christened with the nickname Magriços, finished in a brilliant $3^{\text {rd }}$ place; it was true in 1974 during the Revolution of the $25^{\text {th }}$ of April; it was true during the ceremonies of admission of Portugal to the European Economic Community in 1985; it was true during the coverage of the Gulf War in the early 90 's... ceremonies, large conflicts and international sporting events proved to be at all times worthy of ample media coverage and, as a consequence, represented a step ahead in the evolution of TV. On the other hand, these events made perennial the message of what TV is indeed: a space for collective celebration of a social present.

\section{Television as a place for collective celebration}

Taking television as one of the central elements of social life, we're tempted into looking at its broadcasts as if they were rituals. This is not an innovative comparison. Those who study rites and discover new places for them have already made that comparison, as have those who analyze the television field and argue that a form of communication inspired by rituals comes to life on set. Bringing together the work of different authors, we come across a fertile pathway to rethink the audiovisual as a place for collective celebration and social present that one intends to be as participative as possible. This means that it no longer makes sense to think of television as having two distinct sides: that of the producer of the broadcast and that of the passive receiver of the television message.

Mixing individual time with collective time, linking the present to a reference past, the ritual leaves room for collective mental states, memory stimulation; it changes experiences and exposes a pathway towards disorder. More than transmitting pre-established messages, the rite, through its manifestations, permanently channels new information, becoming in its own right a potential source of knowledge. Composed by specific languages and updated by repetitions that are established in a specific time and space, the ritual manifestations adopt diverse configurations (positive or negative, festive or formal, commemorative or expiatory...), but they all cross, to a greater or smaller degree, with the everyday. Here we speak of rites, but we could reiterate each word, if our referent was television. Writing about primitive rites, Jean Cazeneuve discusses some of its functions that could also be applied to television. Assuming that the "rite is always a symbolic action" (n.d., 269), the French researcher defends that the ritual practices correspond to the needs the individuals have to "set themselves in a human condition and situating that condition in relation to what is avoiding them" (n.d., 279). To reinforce this position, he quotes Saint-Exupéry who, in Citadelle, says that "the rites are in

analyse: (i) the guest/commentators called upon to participate in the information programmes; (ii) the space made available in the information contents for the participation of the viewers.

${ }^{3}$ In Portugal, the TV comes with RTP, operator of public television, whose regular broadcasts dating back to March 7, 1957 For nearly 35 years, RTP operates as a monopoly On October 6, 1992 the first private television channel, SIC, was inaugurated, followed by the second one, TVI, on February 20, 1993. RTP1, RTP2, SIC and TVI are open free-to-air channels. In cable, Portuguese operators offer mainly information thematic channels belonging to the same companies that own open channels: SIC Noticias (created on January 8, 2001) RTPN (created on May 31, 2004) and TVI24 (created on February 26, 2009). 
time what the address is in space". Anchorage points, one could indeed precise, that each and every one of us must be able to actively create.

Circumscribing themselves to particular happenings they have called media events (ME), Daniel Dayan and Elihu Katz also approach television as if it were a ritual. The references for these researches are the "television ceremonies", meaning, "live broadcasts of historical moments that make the country or the world stop" (Dayan and Katz 1999, 17). Promoted by agents outside of television, ME are planned and advertised in advance, creating great expectation in the audience that feels "compelled to watch" and, surely, would like to take place in that which is being broadcasted. According to Dayan and Katz $(1999,23)$, "even when they're dealing with conflicts, they're celebrating reconciliation", constituting themselves, in that way, as "ceremonial efforts to remediate conflict or to restore order or, rarely to establish change". Isn't that what rituals do as well? Going through the literature regarding rites, we can see that there were attempts at distinguishing the ceremonial from the ritual ${ }^{4}$, but these two terms are frequently apprehended together. As far as we're concerned, we look at the ceremony as being an integral part of the ritual, as it is through the ceremonial that the rites are placed on scene and the norms and social values become more expressive. By analyzing the effects of ME, Dayan and Katz $(1999,183-207)$ argue that these events "interrupt the rhythm of people's lives", installing a "time for leisure, but also a sacred time" that demands an "active participation" from the viewers. Notwithstanding that production and reception usually take place in differentiated territories, there should always be a connection from the center (from the scene) with the periphery (places from where you can watch television broadcasts converted, in this respect, to public spaces united by a reterritorialized media scene of the television screen). "Television removes the events from the ground and places them up in the air", argue Dayan and Katz $(1999,30)$.

Live or recorded, television places the viewer before contents broadcasted the same time to a vast audience. There is, in this sense, a present built inside and outside of the small screen that enables the formation of a territorially dispersed community that share, in a given moment, the common mental picture provided in the communicative pact of each program. More important than uncritically watching whatever it is that the networks are broadcasting, it would be of the outmost importance that each and every one of us felt motivated to act on what it is we watch. Today, more than in the recent past, the television device relies on

\footnotetext{
${ }^{4}$ Cf. Wilson, Monica (1957) Rituals of Kinship among the Nyakyusa, Oxford; e Goody, J (1961) "Religion and ritual: the definitional problem", "British Journal of Sociology", 12(2). Attempting to provide the distinction between "ritual" and "ceremonial" with some sort of content, Wilson says that the "ritual" is a religious action destined to obtain benefits from a supernatural power, while the ceremonial is an elaborate and conventional form of expressing feelings, not limited to religious occasions. To Goody, the "ritual" is a category that designs a formalized behaviour (a custom) where the relationship between ends and means is irrational or non-rational. The ceremonial has, in his perspective, a negative definition, designating a category of ritual that is neither religious nor magical, that does not presuppose the existence of supernatural powers, nor does it have any practical ends; it may, however, have ends in regard to the point of view of actors and latent functions from the observer's point of view. For example, the civil marriage ceremonies. Cf. "Cerimonial" in Enciclopédia Einaudi, Vol. 30, Imprensa Nacional Casa da Moeda.
} 
technologies that allow for that connection to be established permanently if television is open to viewer participation and if audiences feel motivated to become active publics.

\section{The hype of the hyper and the centripetous screen}

Despite having outlined a significant portion of its route towards the individualreceptor, the analogically rooted TV that we know today can hardly be seen as interactive: we don't do much more with it than zapping. The broadcast, "a technology of varied messages to a general public" (Williams 1990, 13), organized in the sequential logic of a single timeline, is still being provided in a continual flow that the receiver follows without any major possibility for decisive individual content intervention. We should then analyze why, despite all the technological buzz going on, it seems we're still a bit far from dismissing the theoretical frame set in the early 1970s by English sociologist Raymond Williams who shaped and defined the notion of broadcast TV programming, precisely, as sequence and flow (Williams 1990, 87-96).

The encounter between the digital interactive world and television has been in the making for at least two decades. Even today, as we speak of their ordinary uses, the computer is something different from the television set and the interactive experiences performed by TV since the early 1990s, based on the development of Digital TV technologies, had little continuity (Castells 2004, 224; Cardoso 2006, 243) or kept evolving at a relatively slow pace. Digital TV exists as a technology, but the social use of its full characteristic digitalization features such as interactivity seems to remain relatively distant. Evidence shows that broadcast TV seems to be resisting through old and new forms (Gripsrud 2004, 219; Tay and Turner 2009, 37), which makes it hard to announce the coming of a new era of television or even harder to agree with what we could term as the end is near narrative.

The coming end of television has actually been an ongoing narrative especially since the popularization of the communicational interactive screen, summed up and functionalized by the world wide web. Since the late 1990's, some scholars began to work on ideas of a new television model or even of the end of an era. In 1995, Alejandro Piscitelli suggested that one should begin to consider a post-television. The Argentinean researcher believed that the breakthrough in long distance computing, along with the increase in home edition of video contents, would eventually subdue television as we know it (Piscitelli 1995, 23). He later developed these ideas into a book appropriately titled Post Television (1998).

In line with some of the arguments of Piscitelli, although without using the prefix post, another Argentinean researcher (though working in Spain), Carlos Scolari, presented the concept of hypertelevision. In a 2006 article $^{5}$ where he analyses the consequences of digital hypertextuality in a medium such as TV, this author believes that television has surpassed, indeed, the neo stage, having incorporated, particularly on its fictional narrative structures of the last decade (and, in part, in newscasts) some of the features which seem to be

\footnotetext{
${ }^{5}$ Whose revised and updated English language version was published in 2009 in the Journal of Visual Literacy (vol. 28, nr. 1, pp. 28-49) as The Grammar of Hypertelevision: An Identikit of Convergence-Age Fiction Television (Or, How Television Simulates New Interactive Media), available online at: http://www.ohio.edu/visualliteracy/JVL ISSUE ARCHIVES/JVL28(1)/28 1 Scolari.pdf.
} 
characteristic of the interactive media and the consumption of internet, such as the fragmentation of the screen, the rupture in narrative linearity, the unbridled intertextuality and the quick pace of montage. As a consequence, "hypertelevision needs a consumer educated both in the culture of zapping - characteristic of neo-television - as in the culture of videogames and hypertextual navigation experiences" (Scolari 2006, 10). Essentially through the analysis of new reception features that already incorporate interactivity and individual multi-choice features, the researcher concludes that we're placed before " $a$ new kind of television consumption characterized by the fragmented, ubiquitous and asynchronous: a different show on each set at the same time" which, in Scolari's understanding, breaks up with 50 years of synchronic television, dragging along with it McLuhan's concept of a global village $(2006,13)$. On a subsequent article Scolari would specify his concept as an aesthetical and semiotical approach to the narratives and visuals of the actual TV screen rather than envisioning some sort of interactive television on it. Actually Scolari speaks of a screen that while being unable to be interactive, simulates it $(2008,7)$. The author considers this as a consequence and an adaptation of TV to a new media environment: "these new television textualities - with their multiscreens, transmedia storytelling and multiplication of narrative programs - would be unthinkable without the hypertextual experiences lived by millions of users during the last decade" (idem).

Meanwhile, heavily cited American scholar Amanda D. Lotz also drew on a set of technology-driven arguments on her 2007 book The Television Will Be Revolutionized, to stand not for an end of television as such, but for a post-network era. She starts by arguing that "we may continue to watch television, but the new technologies available to us require new rituals of use" $(2007,2)$. These pre-required new rituals mean a decline in social and spatial-temporal sharing, progressively individualized consumption and the increased possibility for individual content production. Lotz $(2007,7-8)$ considers the mid-1980s as the coming to an end of the network era. A multi-channel transitional period followed until the mid-2000s when clear signs of a technologically revolutionized post-network era finally emerged. Control and mobile technologies, enabling the viewer's own choice, seem to have provided an environment for this kind of developments. Contemporary times would then leave it hard to define "a uniform experience of watching television" (Lotz 2007, 16) as "post-network television is primarily nonlinear rather than linear" (Lotz 2007, 19). Lotz ends her introductory chapter by using and enthusiastically adhering to two quotes on the subject, both by corporate media CEOs.

Actually, as Australian researchers Jinna Tay and Graeme Turner point out, even if it is not immediately perceived, there is a strong alignment of these technology-driven narratives with the current market discourses on TV emerging business models (Tay and Turner 2009, 32). A closer look shows that it has been a geographically specific narrative not applicable to most of the world outside of the western countries (Tay and Turner 2009, 33). And even in the latter countries, this somehow wishful thinking about revolutionalized TV futures hasn't had yet a full translation to the empirical record (Tay and Turner 2009, 57). While staying in the technological buzz of the post-network era, which means insisting that a significant revision of Raymond Williams broadcast flow concept is necessary, "at least in terms of television flow being determined by someone other than the individual viewer" (Lotz 2007, 34), Lotz acknowledges the contradictory evidences that keep showing a steady audience prevalence of prime-time broadcasts over all other forms of TV viewing $(2007,22)$. Lotz' proposal of a post- 
network era also loses ground when applied to the European scenario, where broadcast TV means not only sequence and flow but has a cultural, social, institutional and political meaning as public service, which makes it the focus of public debate around the notion of universal access (Harrison and Wessels 2005, 835) and therefore means a strong centrality to European societies (Moe 2008, 221). Norwegian researcher Jostein Gripsrud seems then to be proven more accurate when he says that "we are still in a social situation that much resembles what was described by Raymond Williams as a set of preconditions for broadcast" $(2004,221)$. Broadcast TV is surely going through changes but still far from demise. Which means we should probably take some alternative perspectives to look (in)to the TV screen.

First, we should assume a commonsensical panoramic view: the living-room central screen is no longer the only technological screen we gaze at, in our everyday life. This has been going on for at least three decades now. So, perhaps there's no strong reason for an ongoing tech-related surprise and blazed astonishment when we constantly find empirical evidences of whatever we call fragmentation, or division of our time and attention towards the technological screens. It becomes quite obvious that we are looking and connecting to different screens all the time, one of them, and surely an important one, still being the old broadcast TV screen to which we find ourselves more laid back than laid forth, more following the flow than disrupting it. This assumption brings us to a non-technologically situated gaze at the screen and raises the question of how should we cope with its evolving processes. This also brings us to an analysis that considers technology as part of a social environment rather than the sole or main driving force of change. Actually this is quite a paradoxical approach as in fact it takes us back to the end of television narrative, but in a different perspective. It draws from research lines other than the digital optimism ${ }^{6}$ of authors such as Piscitelli or Lotz.

By the turn of the millennium, journalist Ignacio Ramonet and semiologist Eliseo Véron agreed that the signs of a demise of broadcast TV were visible just by looking at what the television screens were showing at the time. There was a kind of reality television ${ }^{7}$ that emerged particularly from broadcasts meant for collective voyeurism, such as Big Brother, but that also found its way into other television formats, including those that belonged to the newscasts, promoting the rise of new, disposable and precarious celebrities for which "the symbolic reward is not merely personal satisfaction, the narcissism of having been on television, of one ephemeral appearance (on a game show, a contest, through a testimony). Now, it is becoming a character of a story" (Ramonet 2001). Communicologist Dominique Mehl seemed not to notice any kind of novelty in this, just the exacerbation of the features of a relational neotelevision $(2002,95)$ that the French researcher had already identified during the 1990's. Eliseo Verón, however, added his conviction that a third stage in the history of television, jumpstarted by shows that suggested increasing amounts of voyeurism, was based "on a complex configuration of defined collectives as being exterior to the institution of television, attributable to the non-mediated world of the recipient" $(2001,7)$ that would turn

\footnotetext{
${ }^{6}$ An expression we borrow from Tay and Turner $(2009,32)$.

${ }^{7}$ We should note that especially in the last decade the reality television concept has been developed in various ways by scholars from all over the world, hailing mainly from Europe and north-America. For further in-depth analysis on this subject we would recommend works such as the collective Reality TV - Remaking Television Culture (Susan Murray and Laurie Ouellette, eds., 2009, New York University Press) or François Jost's L'Empire du Loft (2002, La Dispute/Snedit). We also did research on this subject published in 2008 as a book entitled A TV do Real -A Televisão e o Espaço Público (Felisbela Lopes, 2009, MinervaCoimbra).
} 
into the ultimate stage, the one that would decree the end of general public television. In 2006, communicologist Jean-Louis Missika issued a book called La Fin de la Télévision (the end of television) where he further developed these arguments. Following Verón's train of thought, Missika $(2006,7)$ explained that it was not television as technology that was coming to an end but television as media. Drawing on Umberto Eco's periodization, Missika considered that this emerging post-television meant a limited rupture or a further development on the set of neotelevision features. What we see onscreen is then a mix of elements either new or drawn from previous periods (Missika 2006, 20). Post-television (Missika 2006, 27-35) would now correspond to a screen to which the viewer is permanently called in and, unlike the neotelevision screen, he/she has no longer to produce anything extraordinaire to be there. According to Missika this produces an intimacy without interiority $(2006,29)$ and develops a demediation process $(2006,39-53)$. So whether or not I want the screen, the screen wants me in, attracts me in, works its link with me on further identification: "that one who is onscreen is no longer different from me" (Missika 2006, 29).

So, whether we agree or not with (at least, some of the arguments of) the end of television narratives, what are we actually seeing on our TV screens nowadays? If we accept the thesis of an ongoing evolution still based on the broadcasting conceptual frame, we have good reasons to elaborate on an hypothesis that the TV screen may be compensating a possible loss of centrality in people's lives by a developing metamorphosis based on some kind of progressive magnetism: the TV screen emerges as a centripetous screen that attracts, accommodates and combines all sorts of spatio-temporal and socio-semiological resources, in order to retain a central role in our societies. But it isn't only because of its simulational combined and merged features, what Scolari terms as hypertelevision, that we notice its centripetous character. It's also because it truly mobilizes its spectator or, as Missika says, it keeps calling him in, to make him feel he (is not only in but he) is the centre. And also because, as we already argued elsewhere it increasingly tends to summon up, substitute and totalize an idea of public space (Lopes et al. 2011, 229; 237-238). Ours is then a TV screen that calls the individual to the core of the televisive apparatus, playing with his fluid and unstable identity and identifications, with his multiple everyday projections, longings, doubts, frailties and slim real and virtual connections (Bauman 2006, 14-15) which seem to reinforce his narcissistic character (Mourão 2002, 92). However, giving room to a predominance of the ego, this centripetous screen still summons the individual to a multitude of permanent options that also include, in concomitance, the preservation of old communitarian references of a general public TV provider of social synchronicity and communion, democratic participation and shared identity (Wolton 2001, 60-63), alongside all the others that seem to allow him to sketch a completely autonomous, independent and individualized path.

If this proves to be true, the television that we are seeing on our screens behaves as an organic social entity, responding in a social field dynamics to an institutional character that means a continued tendency to position itself in order not to lose its central role or symbolic capital (Bourdieu 1994, 71), both socially and economically. What we say is that this centrality seems to be kept by combining fragmentative and unifying features and merging them into an interchangeable unit by a centripetous process that works by attracting everything to its centre. And this will hardly mean a foreseeable definitive dissolution of the flow-and-sequence basis of the broadcast TV paradigm that also deals with a notion of control over centrality. 


\section{The citizens' place in journalism}

Journalism as a public space for debate is, certainly, one of the key hallmarks of the journalistic field that only makes sense when the discussion promoted is participatory, diversified and brandishes arguments of broad consensus (Kovach and Rosentiel 2004, 140). Concepts such as "participative journalism" and "citizen journalism" become ever more common, but do not always find a great deal of receptivity among journalists nor gather quality contributions from the audience.

One may be able to find the connection between participative journalism and citizen journalism recommended by both the Poynter Institute for Media Studies as by the Pew Center for Civic Journalism. At the genesis of these processes, remains an idea of the public as being participant in the information gathering procedure and in this way providing an important service while helping reporters solve their problems and thus, consequently, increasing the quality of journalism.

With the exception of "citizen journalism", none of the other forms of participatory journalism dispenses the journalist. In fact, they see him as irreplaceable in the partnership established with citizens. There is no journalism without journalists: is what those who see these technological innovations and the inevitable involvement of the audience as distinctive traces of current journalism. The role of pro-active information sources is reserved for citizens who would in turn become some sort of starter of the productive process. The evermore technological environment in which we all circulate has potentiated that dialogue, made possible from the moment the news industry opens effective communication channels. If the journalistic class does not abandon its ongoing responsibilities at the level of information scrutiny, this may turn out to be an interesting alternative pathway for the journalistic field.

In turn, what we call "citizen journalism" envisions that the news content be produced by the citizen that does not need, in order to do that, any journalistic training. It comes down to a kind of "amateur journalism" that may take various shapes: writing of commentary on websites/blogues; sending of photographs/videos; creation of news websites updated by users (for example, the ohmynews website); elaboration of discussion lists, creation of forums; podcasts... The defenders of this new trend, that has in Dan Gilmor (2004) one of its main promoters, point to the democratization of production and the access to information as an inalienable victory of "citizen journalism". There are also those who believe that this is a way to value news reporting, since it adds observation of facts by eyewitnesses. In We Media: How audiences are shaping the future of News and Information, Shayne Bowman and Chris Willis (2003) define this kind of journalism as an act of citizenship were it is the citizen who has an "active role in the process of collecting, reporting, analyzing and disseminating news and information". However, many remain skeptical regarding this understanding. One of the main critiques launched at this kind of journalism is its abandonment of the journalistic principal of objectivity to which citizens are not bound to, allowing for the publication of many "stories" regarding matters to which he that produces content is an interested party. Vincent Maher (2005) says that citizen journalism is linked to the fatal three "E's": ethics, economy and epistemology. Miroljub Radojković (2010) also has many doubts regarding this new role 
entrusted to citizens, questioning if the absence of ethical, professional, cognitive requirements for the exercise of journalism could not bring more harm than good to society.

In the midst of apocalyptical and integrated theses, the journalistic field traces its own path, slowly and in ways that were unpredictable to researchers. In the threshold of digital television, we believe it would be interesting to evaluate how does television information integrate viewers in the contents it produces. The news coverage of the FIFA 2010 World Cup, a media event that attracts mass audiences of different origins, is the motto for this empirical study.

\section{The authorized television voices during the $\mathbf{2 0 1 0}$ World Cup news coverage}

One nation rooting on for a football team, a planet united around pitches that bring together fallen out countries, rich and poor communities, people of different ages and social classes, and of mismatched tastes. It is that glue of the world which brings us closer to one another, that constitutes the magic of an event such as the World Cup. The media, and television in particular, enlarge this sporting event to a planetary scale. It is around the small screen that an invisible community gets together to watch the games and the pre-shows and the debates after the referee has blow the final whistle. In a technological context that potentiates viewer integration in television shows, particularly those that discuss what has happened or will happen on the pitch, it is important to understand to what degree do television networks make that participation possible.

\section{Methodological path}

The World Cup, assuming itself as a media event, in the meaning that Daniel Dayan and Elihu Katz (1999) give this concept, tends to create significant changes in the television programming schedule, which are more visible in the network that hold the broadcasting rights. However, all networks create special information formats to follow up on everything that happens concerning the World Cup or integrate specific contents in existing news shows. The goal is always to attract the interest of the audience, but do those broadcasts really want the audience to be a part of the show or they expect a passive behavior from the viewers? This was the question we tried to answer, having as reference the generalist networks (RTP1, SIC, TVI) and the Portuguese cable news networks (SIC Notícias, RTPN and TVI24) and having as basis for our analysis a set of programs selected in accordance to the criteria we will explain below.

First of all, we selected only news shows which in this case meant those which were hosted by reporters and built upon journalistic criteria, excluding from our investigation all the entertainment contents. This option was only relevant, however, in the generalist channels since contents on news channels are, we expected, essentially informative, though there may be room for a few non-information shows. Having made these distinctions, there are others that should follow. 
In respect to the generalist networks, we decided to only study the newscasts. Regarding the news channels, the constant broadcast of information contents meant that we needed to be a bit more selective. For this reason, we decided to only look at the specific contents created for coverage of the World Cup and the viewer forums that those networks air twice a day and only when the subject of discussion was the World Cup.

Thus, we studied, between the $11^{\text {th }}$ of June and the $11^{\text {th }}$ of July of 2010 (dates of the kick off and closing of the competition), all the news contents of the generalist networks (RTP1, SIC, TVI) and all the contents related to the World Cup and the debate forums on the thematic news channels (SIC Notícias, RTPN, TVI24) when the theme of the broadcast was the World Cup. In the course of study, we took a closer look at the profile of those who were summoned to the studios to discuss this sporting event and the different forms of viewer integration in broadcast. That analysis provided us with 604 broadcasts.

Each broadcast was examined under two distinct levels:

- Plateau composition: we want to know who was invited to be on television broadcasts concerning the World Cup during the time of our study. To map the profile of these guests, we created 5 different variables: geographical provenance, sex, job, relation to the theme of the show and relation to the broadcast.

- Viewer integration: our purpose here is to evaluate how viewers were integrated in information broadcasts and that means understanding which were the participation channels open by news programmers, i.e., which platforms for content access and interaction with the studio are made available to viewers. To discover the routes for public participation in television broadcasts we defined two variables: if viewer integration exists or not; and, in case it does exist, which technology is used to enable that participation (telephone, e-mail, social networks...).

Viewers kept away from the televised debates concerning the World Cup

In Portugal, the World Cup's television did not seem to look for an active viewer. Of the 604 studied broadcasts, only 84 (about 13\%) integrated the viewer, placing at his disposal a few platforms for participation in the news debate, like the telephone or the social networks.

Graph 1: Viewer integration in news programs during the World Cup

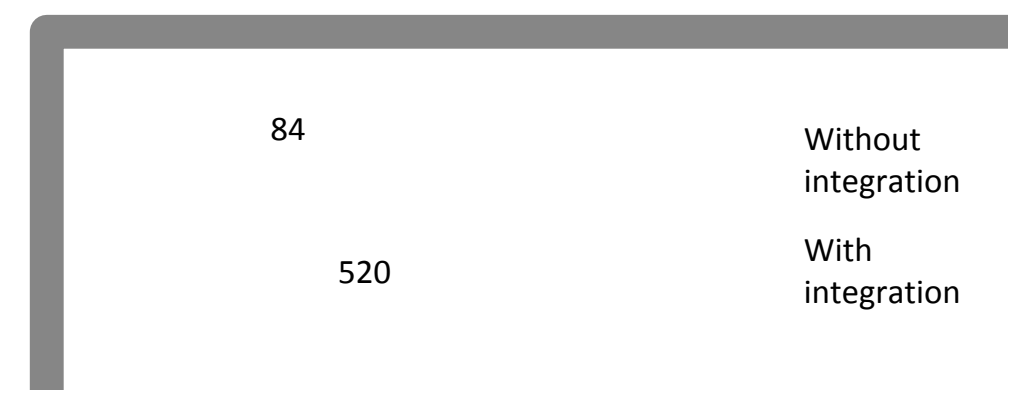


E-mail was, by far, the most commonly used platform for viewer integration in broadcast (in 83 news shows). The telephone and the social networks were used about the same number of times, in 55 and 52 broadcasts, respectively. One should however stress the fact that in most cases these different forms of participation were available at the same time, nevertheless in most cases they were always conditioned and controlled by those who were in charge of the broadcast.

Graph 2: Viewer integration platforms

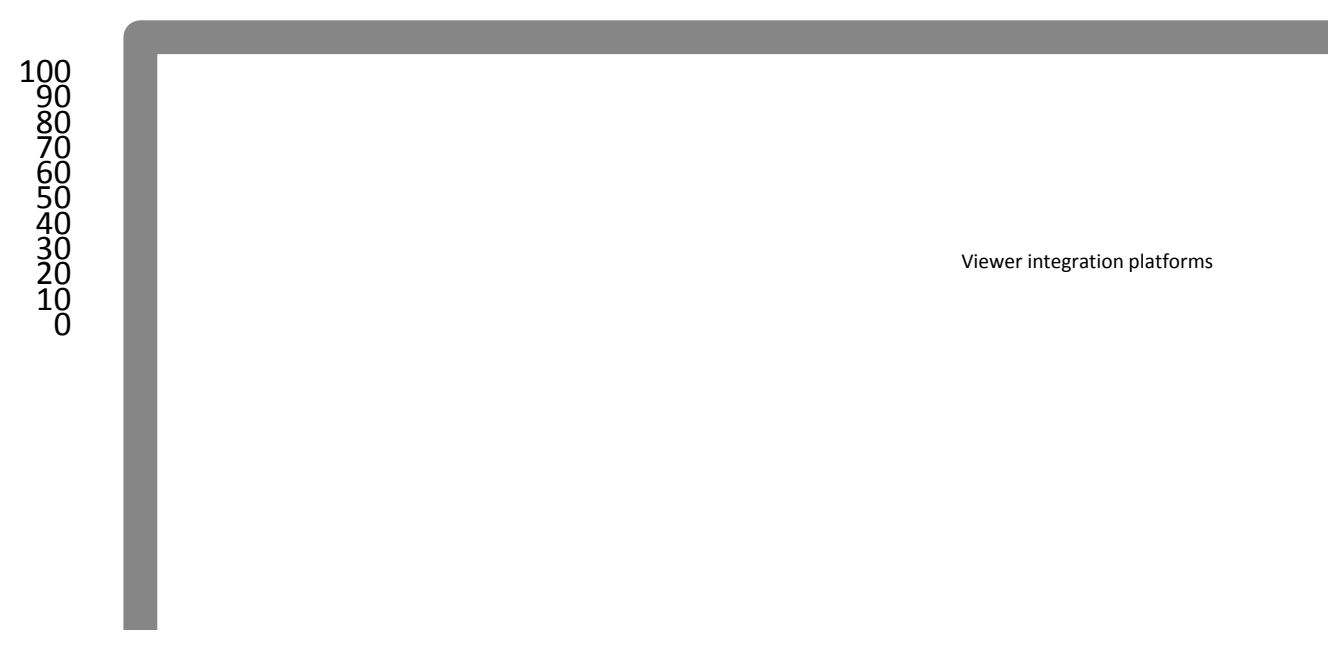

A closer look at our data shows that in the other 520 broadcasts there was no room for the viewer or for his opinion. What this means is that in the vast majority of situations, the networks encouraged an attitude of passive viewing, particularly in the generalist networks since none of them promoted viewer integration in at least one program. The fact is that all of the contents that accepted viewer participation were on cable and most of the time were seen in the debate forums those networks air twice a day. The public service news channel, RTPN, was responsible for the most broadcasts that included viewer integration. In 49 out of a total of 51 programs, RTPN summoned the viewer for debate, although one could only hear his voice in the forums. In other formats, participation reached the television screen through text, that made it to the production of these shows via e-mail or through social networks, such as in the case of À Noite o Mundial, a news show that RTPN created just to cover the World Cup. In studio, besides the anchor, which was in charge of introducing the stories the reporters stationed in South Africa produced and chatting with the guests, there was also a second presenter that from time to time was called upon to read comments and suggestions posted by viewers on the show's Facebook page.

Whether it is cause or consequence, there is one factor that may help us understand why the networks, particularly the generalist ones, seem so distanced from the audience: the 
decision made by SIC and RTP1 (TVI didn't have any particular program in charge of covering the competition) to air short newscasts that presented a synthesis of the information of that day. Those short newscasts consisted of a sole anchor who was in studio and whose soul job was to introduce the news pieces produced by the reporters regarding the World Cup. Furthermore, in our analysis we were able to conclude that in no broadcast under 30 minutes was there any time for viewer integration, which was much more visible in broadcasts that lasted an hour (44 cases) and those that lasted two hours (39). In this sense, there seems to be a relationship between duration of broadcast and viewer integration.

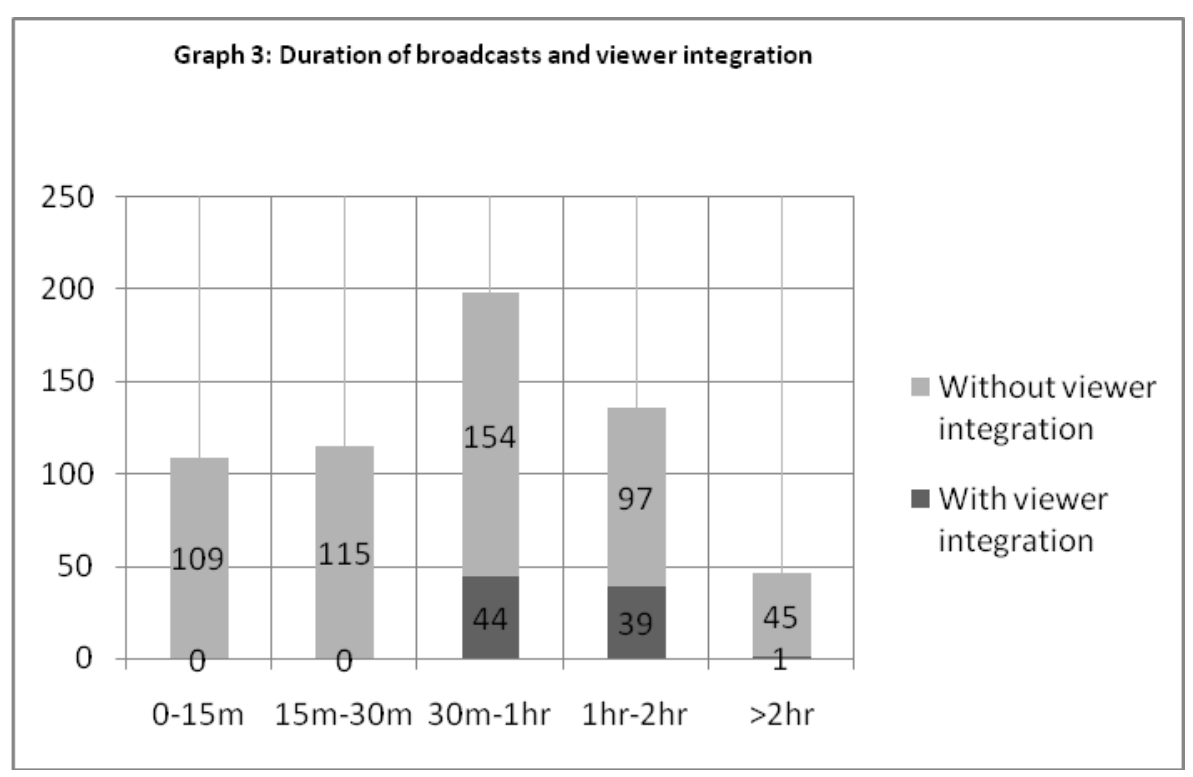

If viewer integration was something that wasn't abundant in television's coverage of the World Cup, in the situations in which it did happen one cannot exactly say there were plenty of traces of innovation. For example, if we look at the forums we can tell that despite the opening of a channel for viewer on air participation there was no room for real discussion and it seems as if the opinions of viewers are merely stacked one on the other. There is no real dialogue with the anchor, or with the guest on set, and there isn't even an exchange of opinions between viewers who have given their opinion. However, what our analysis did tell us is that the telephone is still one of the few options for viewers to enter directly and have their voice heard on television. When it comes to e-mails, for example, viewers only see their comments posted on the screen a posteriori and only after they were screened by the producers. And the same happened regarding new digital platforms, such as social networks, that were hardly explored. 
Faced with this situation, those responsible for sport, particularly for coverage of World Cup 2010 in the various television channels, are divided regarding the potential impact of the participation of viewers on the quality of emissions and on the expression of citizenship. On the side of public television (RTP), journalist Carlos Daniel, RTPN deputy director at the time and pivot of "À Noite, o Mundial", a daily news and debate program dedicated to the World Cup, considers that the participation of viewers, through social networks, email and telephone, has been "excellent" and introduced with the right measure. As an example of the success of this strategy, Daniel points out the Facebook account of his program, which has captured 25 thousand followers in just three weeks. In addition, the introduction of a second pivot on the plateau with the function of interacting with social networks was, in his opinion, "a success" to the point that this model was later adopted by another program "Pontapé de Saída" (Kick-off).

However, on the side of private channels (SIC and TVI) this enthusiasm is not repeated. António Cancela, one of the most notable journalists with editorial role in sport believes that opening emissions to the participation of viewers does not result in a higher level of democratization of contents neither brings commercial added value. On the contrary, he argues, it can break the momentum of the program, causing redundancy in the discussion and reducing the overall quality. Luis Sobral, sports editor for TVI, gives relevance to the presence of the viewers in actual emissions (by phone, email or social networks) to the extent that it "helps to better understand how audiences are living the sporting event." However, in his opinion, it "should not represent more than $5 \%$ of the total program".

Given these statements, it can be said that for private TV operators the viewers' participation is tolerated, while for the public one it seems to be valued.

Journalists with free access to the news set

One of our other elements of analysis sought out to discover who was summoned to be on television to discuss the World Cup. In spite of football being a favorable ground for passionate debates, Portuguese television did not value the conversation formats. One should bear in mind that in $71.3 \%$ of all studied broadcasts the host was the only person on set, showing a clear sign that networks prioritized a traditional approach to the coverage of the competition in prejudice of a more explanatory and/or controversial approach (431 of the 604 broadcasts did not have anyone else on set besides the anchor).

When the news formats did open up to guests on studio, usually they were set in groups that didn't exceed five people. This was the option in 95\% of the analyzed broadcasts. The option of having in between 5 and 10 people on studio was only a reality on 7 shows and 
only one broadcast had more than 10 guests on set: RTP1's debate program Prós e Contras, broadcasted on June $14^{\text {th }}$.

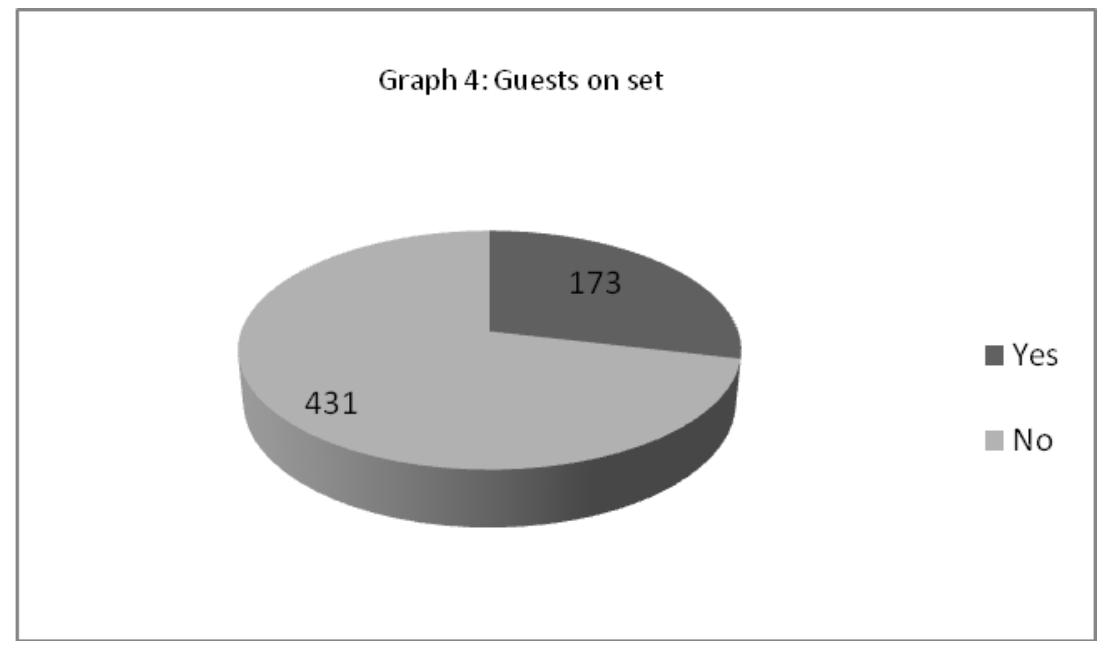

Regarding the guests who were on television during the World Cup, we were also interested in knowing who these people were. To obtain that information we decided to look into their jobs, sex, geographic origin and relation to both program and matter being addressed on the show (in this case, World Cup football). Regarding profession the results leave room for no doubts: journalists covering sports were the most requested professional class to be on television during the 30 days of the World Cup. Out of the 366 guests, 214 were either sports reporters or sports commentators (58.4\%). These numbers are even more overwhelming if we take into account that ex-footballers were the second most sought out professional class with 55 participations in World Cup programs and the third class, coaches, was only on stage 38 times. If we withdraw from our analysis jobs linked to football, the most represented professional class on set was the cultural industry, musicians, actors or directors, who counted 12 presences on set. Politicians from almost all parties were guests on these shows 11 different times. Regarding gender, women were a group that was virtually silenced by the networks: 358 out of the total of 366 guests on these shows were men. Apparently, women did not present themselves as an enabled group when it came to discussing football.

Regarding the geographic provenance of these guests, there was a clear preference for people who came from the Greater Lisbon area. In fact, 238 of the 366 guests (65\%) that were on television discussing the World Cup during the competition hailed from that specific area of the country. The northern region was the second most represented, representing $26.2 \%$ of the total. The rest of the country was practically irrelevant and put aside of this discussion. 
Internationally, Brazil was the only other nationality present in Portuguese broadcasts, accounting for 22 guests in the studio.

Another one of our study variables was the connection between the guest and the theme of the program. In this field, what we tried to know was if the guests' professional profile enabled them to speak about football. At this level, guests with a connection to the theme stick out with 295 appearances, while those who did not have any visible relationship with football were only seen on television talking about it 71 times.

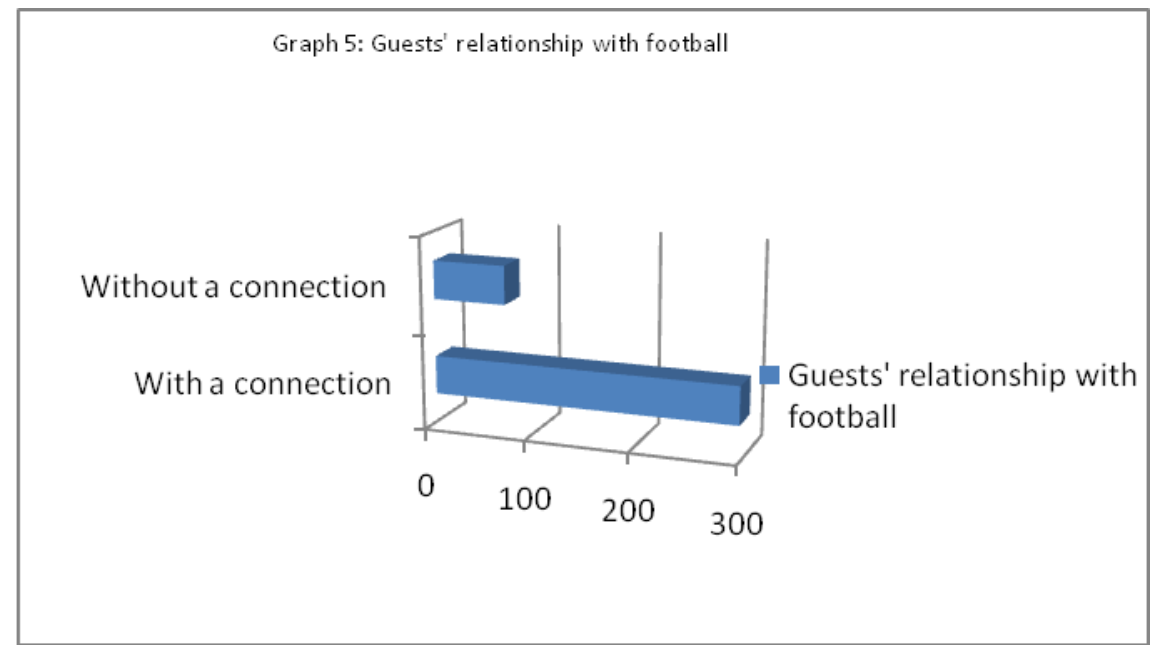

\section{Endnotes}

In relation to information, television during the World Cup was centered in very impermeable contents when it comes to viewer integration. If we take into account that the World Cup is an event that attracts large crowds and is part of a major industry, it would be more than reasonable to assume that the audience would have a much more active role in the television broadcasts concerning the competition. However, that was not the case. The generalist networks, usually associated with the general public (Wolton 1994) were completely impervious to viewer participation in its broadcasts. The cable networks, however, were a bit more willing to give the viewer an opportunity to share his opinion with the general audience. RTPN, the state-owned cable news network, was the channel that by far made the largest effort in integrating the viewers in its broadcasts. Surely, this is a plus for the network that wasn't, however, capable of influencing the groups' generalist channel, RTP1, that did not show a clear interest in presenting itself, as one of its slogans suggests, a "television for every Portuguese", at least not at an information level. 
Looking at Portuguese TV broadcasts aired during the World Cup we're then confronted by a design that is still very similar to the one Umberto Eco created for neotelevision, a television that is mostly interested in attracting an audience, but that is not concerned in transforming its viewers into active partners regarding television production. Empirical evidence underlines the notion of a continuously developing centripetous screen, a screen that attracts everything to its core: the individual viewer, the semiological resources that configure discourse and screen aesthetics, the public debate on any given issue. This screen, however, is still a broadcast TV screen. By being centripetous it shows its capability for continued metamorphosis, for the aggregation and combination of new screen aesthetic elements and discoursive features with the old sequence and flow defining characters of Raymond Williams' broadcasting concept.

It may seem strange that the TV channels had not taken advantage of another event like the World Cup 2010 to motivate the participation of viewers. However, as discussed before, the Portuguese TV is divided regarding the potential impact of that participation to attract more public and enhance the quality of emissions. In public television leaders think there are benefits, but the private side stands quite skeptical. Also interesting is the fact that every single broadcast that allowed for viewer integration was aired on cable, a platform that despite its recent growth and territorial expansion, is still of reduced access and with less visibility.

Concerning the guests summoned by the studios to debate the World Cup, the choice seems to be redundant. Over half of the people who appeared on television were journalists, and this is something that strengthens the "circular news structure" that Pierre Bourdieu mentions (1997). There is a dominant discourse that reflects a given reality, but that does not support all the reality. One must admit that beside everything that was "said" there were also things that remained "unsaid" and this gives room to a huge silent majority of voices that were not heard, the supporters, for example. By confining airtime only to elitist groups, these kind of debates concerning the 2010 World Cup froze the dynamic of the television space. A glance at the news programs that the different networks championed specifically concerning the World Cup, most notably the televised debates, we repeatedly found inflected masculine discourses, that came from interlocutors who live in Lisbon and that belonged to three specific professional groups (journalists, ex-footballers and coaches), with a tendency to listen to the same people over and over again. Surely, the number of people who could promote interesting debates concerning football is wider. 
Taking a glance at the football programming grid there is one aspect that should be underlined: all television networks debuted specific contents to cover the World Cup ${ }^{8}$. This option could have been accompanied by a greater openness to the integration of public participation. Nothing better than an event like the World Cup - which includes different audiences linked together by the passion for football - to motivate viewers to participate and interact with emissions. That was not the option, either because it is considered not to raise audiences or because there is not yet well established and popular models. Therefore this World Cup TV was, above all, a TV dominated by those who produce and present emissions.

The functioning of these centripetous mechanisms has then a meaning related to the notion of control over centrality. Whether the viewer wants to be in or out the screen calls him in. The screen retains control by creating no more than an illusion of choice, participation and interactivity on its viewers: the viewer is then configured by the centripetous screen apparatus as an individualized consumer, not as a political citizen. He is configured as audience rather than public. This brings us to a question that is becoming central to the analysis of public service television, mainly in Europe: if broadcast TV is, as we're suggesting, progressively related to a retainment of control over centrality empirically translated by a competitive fight for audiences, this means a growing dilemma that is undermining the very concept of public service (McQuail 2003, 158-159). While old broadcast television seems to be holding on as sequence and flow its centripetous mechanism seems to work against the very principles of public service. Public service television is then being regarded as competitive with private commercial channels and its central role in societies is no longer clear and becoming increasingly controversial (Moe 2008, 220; Bardoel and d'Haenens 2008, 352-353). This is an ongoing debate that ought to be reflected by further academic research. What we think it's important to underscore is the operability of the centripetous screen concept that needs more scientific insight.

For now empirically gathered evidence allows us to affirm that while Umberto Eco's periodization of broadcast television still holds on and shows a continuous development of its neotelevision characteristic features, the centripetous tendency of the television screen must be closely observed. If a post-television scenario based on a decay of broadcasting seems to be

\footnotetext{
8 On RTP1, "Ligados a Portugal" (short reports inside the preparation of the Portuguese national team) and "Mundial 2010" (newscasts aired before and after the matches and at night); on RTPN, "À Noite, o Mundial" (debate and match analysis); on SIC and SIC Notícias, "Diário do Mundial" (on the generalist network, two daily short newscasts; on cable, several short newscasts aired during the day and a longer emission at night); on TVI24, "Mais Mundial" (match analysis and debate concerning the competition).
} 
put on hold, we cannot say the same about public service television which may sooner than later fall as a victim to an unstoppable centripetous screen apparatus. Thinking the televisive apparatus inside a citizenship frame requires a critical insight that needs to understand the sociological development of the television screen apparatus. Our questioning must then be social and political rather than merely technical.

\section{Bibliography}

Bardoel, J., and d'Haenens, L. 2008. Public Service Broadcasting in Converging Media Modalities: Practices and Reflections from the Netherlands. Convergence: The International Journal of Research into New Media Technologies. Vol. 14, Nr. 3. London: Sage Publications.

Bauman, Z. 2006. Amor Líquido. Lisboa: Relógio d'Água.

Bowman, S., and Willis, C. 2003. We Media: How audiences are shaping the future of News and Information. Virginia: American Press Institute.

Bourdieu, P. 1994. Raisons Pratiques - Sur la Théorie de L'Action. Paris: Editions du Seuil.

Bourdieu, P. 1997. Sobre a Televisão. Oeiras: Celta.

Cardoso, G. 2006. Os Media na Sociedade em Rede. Lisboa: Fundação Calouste Gulbenkian.

Castells, M. 2004. A Galáxia Internet. Lisboa: Fundação Calouste Gulbenkian.

Cazeneuve, J. n.d. Sociologia do Mito. Porto: Rés.

Dayan, D., and Katz, E. 1999. A História em Directo: os acontecimentos mediáticos na televisão. Coimbra: Minerva.

Gilmor, D. 2004. We The Media: Grassroots journalism by the people, for the people. California: O’Reilly Media.

Gripsrud, J. 2004. Broadcast Television: the chances of its survival in a digital age. In Spigel, Lynn; Olsson, Jan (ed.). Television After TV: Essays on a Medium in Transition. Durham: Duke University Press

Harrison, J., and Wessels, B. 2005. "A new public service communication environment? Public service broadcasting values in the reconfiguring media". New Media \& Society Journal, Vol. 7, London: Sage Publications 
Kovach, B., and Rosentiel, T. 2004. Os Elementos do Jornalismo: o que os profissionais do jornalismo devem saber e o público deve exigir. Porto: Porto Editora.

Lopes, F., and Loureiro, L. M. and Vieira, P. 2011. A perda da hegemonia da classe política nos plateaux informativos. Estudos em Comunicação, Nr. 9, May 2011, Universidade da Beira Interior: http://www.ec.ubi.pt/ec/09/pdf/EC09-2011Mai-12.pdf

Lotz, A. D. 2007. The Television Will Be Revolutionized. New York: NYU Press

Maher, V. 2005. Citizen Journalism is Dead, New Media Lab. South Africa: New Media Lab, School of Journalism \& Media Studies: Rhodes University

McQuail, D. 2003. Teoria da Comunicação de Massas. Lisboa: Fundação Calouste Gulbenkian

Mehl, D. 2002. La télévision relationelle. Cahiers internationaux de sociologie 2002/1 , Nr. 112. Paris : Presses Universitaires de France.

Missika, J.-L. 2006. La fin de la télévision. Paris: Editions du Seuil.

Moe, H. 2008. Public service media online? Regulating public broadcasters' internet services A comparative analysis. Television \& New Media Journal. Vol. 9, Nr. 3, London: Sage Publications

Mourão, J. A. 2002. Vínculos, novos vínculos, desvinculações. In Miranda, J. B., and Cruz, M. T. (eds.). Crítica das ligações na Era da Técnica. Lisboa: Tropismos

Piscitelli, A. 1995. Paleo- Neo- y Post-televisión. Del contrato Pedagógico a la Interactividad Generalizada. In Gomez Mont, C. (ed.). La Metamorfosis de la TV. Cuadernos de Comunicación y Práticas Sociales. Mexico City: Universidad Iberoamericana

Piscitelli, A. 1998. Post/Televisión - Ecología de los medios en la era de Internet. Buenos Aires: Paidós Contextos

Radojković, M. 2010. Citizen journalism: New form of communication or new global risk. México: IAMCR (paper).

Ramonet, I. 2001. Big Brother. Le Monde Diplomatique online (Brazilian edition), June edition, 2001. Access 30/03/2008: http://diplo.uol.com.br/2001-06,a182

Scolari, C. 2006. La Estética Posthipertextual, Facultat d'Empresa i Comunicació. Universitat de Vic. Access 31/03/2008:

http://www.uvic.cat/fec/ fitxers/archivos scolari/Scolari Hiperliteratura2006.pdf 
Scolari, C. 2008. Hacia la hipertelevisión. Los primeros sintomas de una nueva configuración del dispositivo televisivo. Diálogos de la Comunicación, Nr. 77, July-Dec 2008, FELAFACS. Access 11/08/2011: http://www.dialogosfelafacs.net/77/articulos/pdf/77CarlosScolari.pdf

Tay, J., and Turner, G. 2009. Not the Apocalypse: Television Futures in the Digital Age. International Journal of Digital Television, Vol. 1, Nr. 1, Bristol: Intellect

Verón, E. 2001. Les publics entre production et reception: problèmes pour une théorie de la reconnaissance. Cursos da Arrábida 2001 - Públicos, Televisão (paper).

Williams, R. 1990. Television - Technology and Cultural Form, $2^{\text {nd }}$. ed., New York: Routledge

Wolton, D. 1994. Elogio do Grande Público: uma teoria crítica da televisão. Lisbon: Edições ASA.

Wolton, D. 2000. E Depois da Internet? Para uma Teoria Crítica dos Novos Médias. Algés: Difel. 